\title{
EUROPA: CUESTIÓN DE MÉTODO
}

\section{EUROPE: A QUESTION OF METHOD}

Enrique Martínez: Centro de Iniciativas de Cooperación al Desarrollo. Universidad de Alcalá de Henares. Madrid (España)

enrique.martinez@uah.es

\section{CURRÍCULUM VITAE}

Secretario General del Centro de Iniciativas de Cooperación al Desarrollo (CICODE) de la Universidad de Alcalá de Henares (España). Autor de varios artículos científicos en libros y revistas universitarias.

\section{RESUMEN}

El método elegido para discutir el próximo y trascendental paso de la integración europea es la convocatoria de una conferencia intergubernamental. En ésta se discutirá el texto final de la Constitución Europea. Esto supone una vuelta al método tradicional de construir Europa. En cada una de ellas se han firmado documentos importantes para el futuro de Europa, como el Acta Única Europea o la formación del Consejo Europeo de Niza.

\section{PALABRAS CLAVE}

Europa - Integración - Conferencia intergubernamental - Constitución Europea 


\begin{abstract}
The method chosen to discuss the next step and far-reaching European integration is the convening of an intergovernmental conference. In this final text will discuss the European Constitution. This represents a return to the traditional method of building Europe. In each of these important documents have been signed for the future of Europe, the Single European Act or the formation of the European Council of Nice.
\end{abstract}

\title{
KEY WORDS
}

Europe - Integration - Intergovernmental Conference - European Constitution

\section{TEXTO:}

La Convención ha hecho sin duda una gran aportación a la construcción de la Europa Unida. El método elegido para discutir el próximo y trascendental paso de la integración europea supone un salto cualitativo respecto a anteriores reformas. Sin embargo, la exigencia de la convocatoria de una conferencia intergubernamental (CIG) para discutir el texto final de la Constitución Europea supone una vuelta al método tradicional de construir Europa.

Efectivamente, las discusiones en el seno de la CIG se producen en clave de interés nacional y no a la vista del interés comunitario -deberíamos empezar a decir el interés "europeo"-. Ello condiciona enormemente el modus operandi mediante el cual se pretende llegar al objetivo final de una Constitución para Europa. Y en la elección del método reside, en nuestra opinión, buena parte del éxito o del fracaso en la 
empresa. Demos una pequeña vuelta por el pasado con el fin de entender mejor todo esto.

La CIG que condujo a la redacción del Acta Única Europea (AUE) y las dos CIG de 1991 estuvieron marcadas por la utilización del método de sinergias, que se manifestó en extremo eficaz. Ciertamente, ambas CIG deben encuadrarse en lo que podríamos llamar el fin de la "época de las decisiones verticales", es decir, los procesos de toma de decisiones estaban constreñidos -en términos de información como de capacidad operativa- a lo que el profesor Sidjanski ha denominado con acierto la "eurosfera". Negociadores altamente especializados abrían consultas limitadas en el marco de las instituciones y obtenían un resultado como fruto de un compromiso al margen de la ciudadanía y de sus representantes. Fuertes personalidades europeas, como Jacques Delors, iniciaron los procesos y estos fueron discurriendo por la "eurosfera" (COREPER, equipos negociadores en la CIG, comités consultivos) hasta alcanzar el compromiso final.

Amsterdam marca una etapa de transición entre ésta y la "época de las decisiones horizontales". En efecto, para abordar las reformas pospuestas en el Tratado de la Unión Europea (TUE) se crea el Grupo de Reflexión, que si bien es cierto se trataba de una instancia altamente especializada, no por ello dejó de abrir consultas con los agentes socioeconómicos (empresarios y sindicatos), grupos de interés, partidos políticos, así como los medios universitarios. El resultado es bien conocido. La etapa de reflexión fue rica en resultados pero la exigencia final de culminar el proceso de toma de decisiones en una CIG dio al traste con cualquier esperanza de avance significativo en la construcción de la Europa Unida. Los grandes retos institucionales se pospusieron para una CIG que se celebraría en al año 2000.

Esta CIG, que desembocaría en el Consejo Europeo de Niza, supuso la culminación del proceso inacabado de Amsterdam. Considerada innecesaria cualquier reflexión 
adicional, Europa entera asistió al triste espectáculo de unos acuerdos cerrados apresuradamente a altas horas de la madrugada de los que salió un texto fruto de un apurado consenso que -dicho sea como anécdota- contenía incluso errores en la versión entregada a los medios de comunicación que más tarde tuvieron que ser corregidos. Improvisación, dudas, en definitiva un escenario de confrontación de intereses nacionales al margen del interés de la Europa Unida, produjeron el peor acuerdo fruto de la aplicación del peor de los métodos.

Ello determinó que en lo sucesivo se inaugurase un proceso de toma de decisiones más amplio, abierto a un mayor número de actores e intereses y con mayor profundidad en los debates. De ahí surge con fuerza la idea de la Convención cuyo método recuerda al de las "Assises Européennes" de Roma de 1990 que reunieron a los Parlamentos Nacionales en torno al debate previo a las CIG de 1991 y, más recientemente, al proceso que condujo a la aprobación de la Carta Europea de los Derechos Fundamentales. Es preciso decir que la idea Convención presenta tintes jacobinos no solo en su denominación sino también en el proceso seguido para elección de sus miembros. El espectro de intereses y concepciones de Europa se amplía, es cierto, pero la conexión con los ciudadanos sigue siendo débil: en definitiva, no se trata de un Asamblea Constituyente.

El destino final del resultado de los trabajos de la Convención no hace sino sacar a la luz del día lo que muchos ya sabíamos. Sus conclusiones han de seguir un proceso de toma de decisiones encuadrado en el método intergubernamental, cuya máxima expresión son las CIG, que no es el que mejor se adapta al cuaderno de tareas principal: la redacción de un proyecto de Constitución Europea. De ahí que no resulte extraño el hecho de que los acuerdos de Niza se vean como un paso atrás en la construcción de una estructura institucional capaz de hacer efectivo y equilibrado a un tiempo el proceso de toma de decisiones en las instituciones clave de la Unión: Consejo y Comisión. 
No obstante, inmersos ya en la "época de las decisiones horizontales", la Convención termina su mandato de redactar un proyecto de Constitución Europea y deja paso nuevamente a una CIG y no a una Asamblea Constituyente. Grave contradicción que cualquiera pudo advertir al inicio del proceso: las decisiones horizontales terminan por adoptar forma jurídica en un escenario vertical. Por ello en Nápoles -como probablemente sucederá en Bruselas- han surgido de nuevo tensiones entre los Estados miembros o, lo que es lo mismo, el interés nacional ha aflorado en detrimento del interés común Europeo. Y no se trata de que Polonia o España "pierdan o ganen" -frase por desgracia recurrente en los últimos tiempos dentro el vocabulario de los políticos europeos- en términos de ponderación del voto en el seno del Consejo y en la consiguiente formación de minorías de bloqueo. La cuestión radica, por el contrario, en que los acuerdos se construyen sobre la base de una legitimidad espuria -la del método intergubernamental propio de la "época de las decisiones verticales"- mientras que el objetivo superior, la Constitución Europea, requiere una legitimidad más amplia y elaborada -la del método supranacional, propio del enfoque federalista, que corresponde a la "época de las decisiones horizontales"-. La formulación práctica en el caso que nos ocupa implicaría la convocatoria con posterioridad a los trabajos de la Convención de una Asamblea Constituyente Europea.

Muchos considerarán que el sentido práctico que ha inspirado la construcción comunitaria en estos cincuenta años de andadura común terminará imponiéndose y la negociación, principio básico del proceso comunitario dará paso a un acuerdo globalmente satisfactorio. Lo cierto es que hay momentos como el presente en el que el mero balance de poderes y la resolución de la ecuación del interés nacional ya no son de utilidad. El acuerdo que finalmente se adopte en Bruselas corre el riesgo de no ser el acuerdo que la Europa Unida necesita. Además, se advierte claramente que en el momento actual la ayuda fundamental prestada por las grandes figuras europeas - 
que fue trascendental en la "época de las decisiones verticales"- brilla por su ausencia. Lamentablemente, no hay líderes europeos la altura de las circunstancias.

Por ello, en interés del objetivo fundamental de alcanzar el estadio final de la construcción europea, factor clave en el desarrollo futuro de las relaciones internacionales, apelamos desde aquí a que todos quienes han seguido el proceso de reforma institucional desde sus orígenes y comparten nuestra idea de que ha llegado la hora de adaptar el método europeo a la "época de las decisiones horizontales", se sumen a nuestra petición de sentar las bases para la convocatoria de una Asamblea Constituyente Europea que permita con éxito culminar el sueño de una Europa Unida. Una Europa Unida susceptible de ser eficaz y equilibrada a un tiempo, en la que el interés general europeo sea capaz de primar sobre la mera suma -tantas veces equívoca y desigual- de los intereses nacionales. 